\title{
HERITABILITAS BOBOT TELUR, BOBOT TETAS DAN BOBOT BADAN AYAM HASIL PERSILANGAN UMUR 1 MINGGU (DOC)
}

\author{
Seftiyanti Masili, Safriyanto Dako, Fahrul Ilham, Syukri I. Gubali \\ Animal Husbandry department, Agriculture Faculty, Gorontalo State University \\ Septiyantimasili@gmail.com. sdako@ung.ac.id. filham@gmail.com. sgubali@ung.ac.id
}

\begin{abstract}
ABSTRAK
The aim was to determine the heritability of egg weight, hatch weight, age of a week body weight in crossbred chickens. This research was conducted from August-November 2017, in Tumbihe Village, Kabila District, Bone Bolango District, Gorontalo province. The research material was eggs and DOC originating from a cross between male Kampung chicken and female Leghorn chicken, Isa Brown strain, these eggs were weighed and hatched in a hatchery machine. The parameters measured were egg weight heritability, hatch weight, 1 week body weight in crossbred chickens. Data were analyzed by descriptive statistics. The results of this study are the heritability of egg weight in the population is $0.533 \pm 0.03$ and the variance coefficient is $6.16 \%$. The heritability of hatch weight in the population is $0.532 \pm 0.02$ and the variance coefficient is $4.33 \%$. While the heritability value of 1 week age weight in the population is $0.530 \pm 0.02$ and the variance coefficient is $3.26 \%$.
\end{abstract}

Kata Kunci : Heritability, egg weight, hatch weight, age of a week body weight

\section{PENDAHULUAN}

Peran ayam kampung lokal sebagai penghasil telur maupun daging, sangat berarti bagi masyarakat walaupun kemampuan produksi ayam ini rendah dibanding dengan ayam ras petelur dan ras pedaging (Dako dkk, 2018), selain itu, pertumbuhan ayam kampung lokal lambat disebabkan rendahnya mutu genetik. Perbaikan genetik dapat dilakukan sebagai upaya menghasilkan ayam kampung yang memiliki produksi telur yang tinggi, pertumbuhan yang cepat, dan ketersediaan bibit yang berkualitas. Perbaikan mutu genetik ternak melalui seleksi dan persilangan ditentukan oleh kekuatan pewarisan sifat yang diperbaiki dan diturunkan pada generesai berikutnya. Nilai heritabilitas mengarah pada kekuatan pewarisan dari tetua pada keturunannya. Nilai parameter genetik suatu sifat pada suatu populasi dapat digunakan sebagai salah satu petunjuk kearah mana langkah-langkah perbaikan mutu genetik populasi tersebut. Pada kondisi tertentu, parameter suatu sifat mempunyai nilai heritabilitas yang tinggi maka seleksi individu merupakan metode yang tepat dalam perbaikan mutu genetik sifat tersebut karena respon seleksi yang diharapkan lebih besar dibanding sifat dengan heritabilitas genetik yang rendah. Informasi tentang heritabilitas menjadi dasar dalam proses seleksi selanjutnya. 


\section{METODE PENELITIAN}

Penelitian telah dilaksanakan dari Agustus-November 2017 di Kelurahan Tumbihe, Kecamatan Kabila, Kabupaten Bone Bolango, Provinsi Gorontalo. Penelitian ini menggunakan telur ayam hasil persilangan sebanyak 300 butir. Telur ini berasal dari persilangan 3 pejantan ayam kampung (3 ekor) dan ayam leghorn betina strain Isa brown (30 ekor), perbandingan 1:10. Metode Inseminasi buatan digunakan dalam perkawinan antar induk, dengan pengenceran semen 1:3.

Pengumpulan telur dilakukan setiap hari, selanjutnya dilakukan pengukuran. Masa simpan telur tetas selama 7 hari. Mesin Tetas yang digunakan adalah mesin tetas otomatis berkapasitas 200 butir. Untuk menghindari kekurangan data penetasan telur di ulangi sebayak 3 kali.

\section{Parameter yang di ukur}

Parameter yang diukur adalah: Heritabilitas bobot telur, bobot tetas dan bobot badan umur seminggu. Heritabilitas dihitung berdasarkan fulshib corelation menggunakan rumus yang digunakan Agroland, J (2009) yaitu:

$$
\mathrm{h}^{2}=\frac{2 \sigma^{2} \mathrm{~S}}{\sigma^{2} \mathrm{~S}+\sigma^{2} \mathrm{~W}}
$$

Keterangan:

$$
\begin{array}{ll}
\mathrm{h}^{2} & =\text { Heritabilitas } \\
\mathrm{\sigma}^{2} \mathrm{~S} & =\text { Ragam Pejantan } \\
\mathrm{\sigma}^{2} w & =\text { Ragam Anak }
\end{array}
$$

1. Menghitung nilai heritabilitas bobot tetas

2. Menghitung nilai heretabilitas bobot badan umur 1 hari sampai 1 minggu.

\section{Analisis Data}

Data yang diperoleh dari dianalisßs $=X_{m \text { se }} \gamma_{\text {ara }}$ deskriptif dengan mengikuti Indrawati dkk (2015), yaitu sebagai berikut:

1. Nilai Maksimum dan Nilai Minimum

$$
\begin{aligned}
& \text { Rata-rata/Mean (X) } \\
& \bar{x}=\frac{x_{1}+x_{2}+\ldots+x_{\mathrm{n}}}{n} \text { atau } \bar{x}=\sum_{i=1}^{n} \frac{x_{i}}{n}
\end{aligned}
$$

2. Simpangan Baku

$$
S=\sqrt{\frac{\sum_{i=1}^{n}\left(X_{i}-\bar{X}\right)^{2}}{n-1}}
$$

3. Koefisien Variasi

$$
K V=\frac{s}{\bar{X}} \times 100 \%
$$

\section{HASIL DAN PEMBAHASAN}

\section{Nilai Heritabilitas Bobot Telur}

Nilai heritabilitas bobot telur berdasarkan korelasi fullsib ayam hasil persilangan diperoleh pada penelitian ini disajikan pada Tabel 6 .

Tabel 6. Nilai heritabilitas bobot telur berdasarkan korelasi fullsib

\begin{tabular}{ccccc}
\hline $\mathrm{P}$ & $\mathrm{A}$ & $\mathrm{B}$ & $\mathrm{C}$ & Total \\
\hline 1 & 0.55 & 0.50 & 0.52 & \\
2 & 0.58 & 0.55 & 0.57 & \\
3 & 0.52 & 0.53 & 0.51 & \\
4 & 0.51 & 0.57 & 0.48 & \\
\hline Total & 2.17 & 2.15 & 2.08 & 6.40 \\
\hline Rataan & 0.540 & 0.5375 & 0.520 & 0.533 \\
\hline Stdev & 0.032 & 0.031 & 0.037 & 0.032 \\
\hline Covar & 0.059 & 0.055 & 0.0710 & 0.062 \\
\hline \multicolumn{5}{c}{ Berdarkan tabel diatas, }
\end{tabular}

heritabilitas bobot telur hasil persilangan setiap populasinya adalah 0.54, 0.54, dan 0.52 . 
Rataan seluruh bobot telur populasi adalah 0.53 . Hasil penelitian ini menggambarkan nilai heritabilitas bobot telur termasuk tinggi. Kategori besar kecilnya nilai heritabilitas, yaitu: $\mathrm{h}^{2}<0$, 20 rendah; $0,20-0,40$ sedang dan $>0,40$ tinggi. Standar deviasi nilai heritabilitas bobot telur ditiap pejantan sesuai tabel 6 adalah $0.03,0.03$, dan 0.04 dengan rataan nilai standar deviasi untuk nilai heritabilibilitas adalah 0.01. Hal ini menunjukkan bahwa penyimpangan nilai rata - rata untuk nilai heritabilitas bobot telur keseluruhan populasi tiap - tiap kelompok pejantan sebesar 0.01. Nilai koefisien variasi dari nilai heritabilitas bobot telur ditiap pejantan sesuai tabel 6 adalah 0.05, 0.06, dan 0.07. Menurut (Ijas, 2012), suatu kelompok data dikatakan lebih homogen dari pada kelompok data lainnya apabila nilai koefisien variasinya lebih kecil atau dibawah $10 \%$.

\section{Nilai Heritabiltas Bobot Tetas}

Nilai heritabilitas bobot tetas berdasarkan korelasi fullsib hasil persilangan antara pejantan ayam kampung dan betina ayam leghoron strain isa brown yang diperoleh pada penelitian ini disajikan pada tabel 7 .

Tabel 7. Nilai heritabilitas bobot tetas berdasarkan korelasi fullsib

\begin{tabular}{ccccc}
\hline $\mathrm{P}$ & $\mathrm{A}$ & $\mathrm{B}$ & $\mathrm{C}$ & Total \\
\hline 1 & 0.54 & 0.57 & 0.50 & \\
2 & 0.52 & 0.51 & 0.55 & \\
3 & 0.52 & 0.53 & 0.50 & \\
4 & 0.53 & 0.54 & 0.57 & \\
\hline Total & 2.11 & 2.16 & 2.12 & 6.38 \\
\hline Rataan & 0.528 & 0.538 & 0.530 & 0.532 \\
\hline Stdev & 0.010 & 0.025 & 0.036 & 0.023 \\
\hline Covar & 0.018 & 0.047 & 0.067 & 0.044 \\
\hline
\end{tabular}

Berdasarkan tabel 7 diatas, nilai heritabilitas bobot tetas hasil persilangan setiap populasinya adalah $0.53,0.54$, dan 0.53 . Rataan bobot tetas seluruh populasi adalah 0.53. Dari penjelasan sebelumnya bahwa bobot telur sangat mempengaruhi bobot tetas, sehingga nilai heritabilitas bobot tetas juga dipengaruhi.

Standar deviasi dari nilai heritabilitas bobot tetas ditiap pejantan sesuai tabel 7 adalah $0.01,0.02$, dan 0.04 dengan rataan standar deviasi adalah 0.01. Hal ini menunjukkan bahwa penyimpangan nilai rata - rata untuk nilai heritabilitas bobot tetas keseluruhan populasi tiap - tiap kelompok pejantan sebesar 0.01 . Koefisien variasi dari nilai heritabilitas bobot tetas ditiap - tiap pejantan sesuai tabel 7 adalah $0.02,0.04$, dan 0.07 dengan rataan nilai koefisien variasi untuk heritabilitas bobot tetas adalah 0.01 .

\section{Heritabilitas Bobot Badan umur seminggu}

Nilai heritabilitas bobot badan umur 1 minggu berdasarkan korelasi fullsib hasil persilangan antara pejantan ayam kampung dan betina ayam leghoron strain isa brown yang diperoleh pada penelitian ini disajikan pada tabel 8 .

Tabel 8. Nilai heritabilitas bobot badan umur 1 minggu berdasarkan korelasi fullsib

\begin{tabular}{ccccc}
\hline $\mathrm{P}$ & $\mathrm{A}$ & $\mathrm{B}$ & $\mathrm{C}$ & Total \\
\hline 1 & 0.52 & 0.52 & 0.51 & \\
2 & 0.51 & 0.54 & 0.50 & \\
3 & 0.56 & 0.55 & 0.52 & \\
4 & 0.55 & 0.54 & 0.54 & \\
\hline Total & 2.13 & 2.16 & 2.08 & 6.37 \\
\hline Rataan & 0.535 & 0.538 & 0.518 & 0.530 \\
\hline Stdev & 0.024 & 0.013 & 0.017 & 0.018 \\
\hline Covar & 0.044 & 0.023 & 0.033 & 0.034 \\
\hline
\end{tabular}

Berdasarkan tabel 8 diatas, nilai heritabilitas bobot badan umur seminggu ayam hasil persilangan disetiap populasinya adalah $0.53,0.54$, dan 0.52. Rataan seluruh bobot telur populasi adalah 0.53. Hal ini 
menunjukan angka pewarisan sifat yang diwarisi oleh keturunannya disebabkan oleh genetic, sehingga kecil kemungkinan pengaruh dari pada lingkungan itu sendiri. Standar deviasi dari nilai heritabilitas bobot badan umur 1 minggu tidak jauh berbeda dengan nilai heritabilitas bobot telur dan bobot tetas. Nilai standar deviasi untuk angka pewarisan sifat ini adalah 0.02, 0.01, dan 0.02 dengan rataan standar deviasi nilai heritabilitas bobot badan umur 1 minggu adalah 0.01 . Koefisien variasi dari nilai heritabilitas bobot badan umur 1 minggu ditiap - tiap pejantan sesuai tabel 8 adalah $0.04,0.02$, dan 0.04 dengan rataan nilai koefisien variasi untuk heritabilitas bobot badan umur 1 minggu adalah 0.02 .

\section{KESIMPULAN}

Heritabilitas bobot telur hasil persilangan memiliki rataan $0.53 \pm 0.01$, koefisien variasinya 0.02 . Bobot tetas 0 . $53 \pm 0.01$ dengan koefsien variasinya 0.01 . Heritabilitas bobot badan ayam umur seminggu $0.53 \pm 0.01$ dengan koofisien variasinya 0.02 .

\section{DAFTAR PUSTAKA}

Agroland, J 2009. Nilai Heritabilitas

Dan Korelasi Genetik Sifat Pertumbuhan Dari Silangan Ayam Lokal Dengan Ayam Bangkok. Universitas Tadulako. Palu. Vol $1:$ 67-71.

Anggorodi, 2009. Beternak Ayam Kampung. Karya Anda. Surabaya

Budi, U., Bachari, I., dan Lisma, P.R. 2008. Penambahan tepung cangkang telur Ayam ras pada ransum terhadap fertilitas, daya tetas dan mortalitas Burung
Puyuh. Jurnal Agribisnis Peternakan 4: 111-115.

Dako S., Ilham F., N. K Laya, Fathan S., Azar M., M. Labado. 2018. Persilangan ayam Kampung dan ayam Leghorn Strain Isa Brown. Frontiers: Jurnal Sains Dan Teknologi 1 (2)

Ijas, 2012. Strategi Pengembangan Ayam Biromaru Dalam Upaya Penyediaan Bibit Ayam Pedaging Lokal. Universitas Tadulako. Palu. Vol: 2(2) 66-67

Indrawati, E., Saili, T., dan Rahadi, S., 2015. Fertilitas, Daya Hidup Embrio, Daya Tetas Dan Bobot TetasTelur Ayam Ras Hasil Inseminasi Buatan Dengan Ayam Tolaki. JITRO, Vol.1.No.3.Mei 2015

Kurnianto, 2009. Membuat dan Mengelola Mesin Tetas. Penebar Swadaya. Jakarta.

Kaharudin, 2010. Pembibitan Ayam Ras. Penebar Swadaya. Jakarta.

Pamungkas, F.A. 2005. Beberapa Kriteria Analisis Penduga Bobot Telur, Bobot Tetas Dan Bobot Hidup Umur 1 Minggu Dalam Seleksi Ayam Kampung. Institut Pertanian Bogor. Bogor. JITV Vol 10

Suprijatna, E. 2010. Strategi Pengembangan Ayam Lokal Di Indonesia. Fakultas Peternakan Universitas Diponegoro. Badan Penerbit Universitas Diponegoro. Semarang 
Srivin, Dako S dan Ilham F. 2016. Korelasi ukuran-ukuran Tubuh Ayam kampung di Pesisir Pantai Selatan Kabupaten Bone-Bolango Provinsi Gorontalo, Jurnal Belibis Sains, Vol 1 hal 7-17 